\title{
OPTIMALISASI KARTU KENDALI PADA SISTEM INFORMASI PENDATAAN SURAT MASUK DAN SURAT KELUAR
}

\author{
Sri Rahayu ${ }^{1}$ \\ Syarah $^{2}$ \\ Dara Hana Wardani ${ }^{3}$ \\ Dosen STMIK Raharja ${ }^{1}$ \\ Dosen Dharma Putera ${ }^{2}$ \\ STMIK Raharja Jurusan Sistem Informasi ${ }^{3}$ \\ Jl. Jenderal Sudirman No. 40, Moderland Tangerang ${ }^{1,2,3}$ \\ Email : srirahayu@raharja.info ${ }^{1}$,uni.syarah09@gmail.com ${ }^{2}$,dara.hana@raharja.info ${ }^{3}$
}

\begin{abstract}
ABSTRAK
Saat ini, untuk tercapainya sebuah informasi yang cepat dan akurat tidak terlepas dari sistem informasi yang dibangun dengan baik. Begitu pula dengan sistem pendataan surat masuk dan surat keluar. Banyaknya jumlah surat masuk dan surat keluar setiap harinya pada SMK Negeri 5 Tangerang membuat user merasa kesulitan saat melakukan pengelolaan data karena data harus diproses ulang, hambatan pada Kartu Kendali, juga pada saat pembuatan laporan, selain itu user kesulitan saat melakukan pencarian surat. Dalam pembuatan Sistem Informasi Surat Masuk dan Surat Keluar, Sistem membutuhkan data untuk diolah sehingga menghasilkan informasi yang sesuai dengan yang dibutuhkan. Adapun beberapa informasi yang dibutuhkan bagian Tata Usaha adalah informasi hasil verifikasi yang bersumber dari Kartu Kendali, informasi lainnya adalah hasil dari proses pencarian data surat masuk dan surat keluar yang sudah pernah diproses yang tersimpan dalam database. Dengan adanya aplikasi yang disediakan, maka tidak ada hambatan lagi bagi Tata Usaha dalam memproses laporan harian surat masuk dan surat keluar dan mencari informasi mengenai surat-surat yang dibutuhkan. Sistem juga memberikan kemudahan bagi user (Tata Usaha) saat akan membuat laporan setiap akhir bulan, karena data yang dimasukkan setiap hari secara otomatis digeneralisasi menjadi laporan.
\end{abstract}

Kata kunci : Sistem Informasi, Kartu Kendali, Surat Masuk dan Surat Keluar

\begin{abstract}
Currently, to achieve a fast and accurate information can not be separated from the system that well constructed. Similarly, the data collection system of incoming mail and outgoing mail. A large number of incoming and outgoing mail every day at SMK Negeri 5 Tangerang, make the user experience difficulty in managing data because the data have to be reprocessed, constraints on control card, also at the time of making the report, in addition to the user difficulties when searching a letter. In the manufacture of Information Systems Incoming Mail and Outgoing Mail, System requires the data to be processed to produce the information as required. As for some of the information required the Administration is the result of the verification information sourced from Control Card, other information is the result of the data search process incoming and outgoing mail that have been processed are stored in the database. With the application provided, then there are no more obstacles for the Administration to process daily reports of incoming mail and outgoing mail and searching for information on the required paperwork. The system also makes it easy for the
\end{abstract}


user (Administration) will make a report when the end of each month, because the data are entered every day automatically generalized into a report.

Keywords : Information Systems, Control Card, incoming mail and outgoing mail

\section{PENDAHULUAN}

Saat ini, untuk tercapainya sebuah informasi yang cepat dan akurat tidak terlepas dari sistem informasi yang dibangun dengan baik. Begitu pula dengan sistem pendataan surat masuk dan surat keluar pada sebuah instansi, perusahaan, sekolah, perguruan tinggi dan sebagainya. Akan terasa sangat menyulitkan pekerjaan user jika sistem masih berjalan manual dengan cara mencatat kedalam buku besar, terlebih jika keluar masuknya surat sudah berjumlah banyak setiap harinya. Banyaknya hal yang harus dicatat seperti nomor, nama penerima, nama tujuan, perihal, tanggal dan lain sebagainya. Hal ini menyebabkan tingginya tingkat pencatatan terutama dalam pencatatan nomor surat. Begitu juga tentang kerapihan penyimpanan berkas, jika penyimpanan surat tersebut tidak sesuai dengan jenis surat atau kategori surat, maka hal ini dapat menyebabkan proses pencarian surat menjadi lambat, bahkan tak jarang surat yang dimaksud tidak ditemukan padahal sebenarnya surat itu ada. Hal ini pula akan menyebabkan keterlambatan pembuatan laporan akhir bulan kepada pimpinan mengenai surat masuk dan surat keluar. Untuk efisiensi kerja, dibutuhkan suatu sistem yang mampu mengelola data secara sistematis, mengelompokan surat masuk surat keluar sesuai dengan jenis surat, pencarian data yang mudah dilakukan, sampai pada pembuatan laporan yang cepat dan akurat.

\section{PERMASALAHAN}

Banyaknya jumlah surat masuk dan surat keluar setiap harinya pada SMK Negeri 5 Tangerang membuat user merasa kesulitan saat melakukan pengelolaan. Data surat masuk dan surat keluar yang di-input pada buku besar harus dikelola kembali untuk dibuat laporannya kepada pimpinan, hal ini membutuhkan waktu yang lama karena data harus diproses ulang, proses ulang bukan hanya pada Kartu Kendali, tetapi juga pada saat pembuatan laporan kepada pimpinan. Permasalahan lain yaitu user kesulitan saat melakukan pencarian surat, baik surat masuk ataupun surat keluar. Saat penyimpanan surat tersebut tidak sesuai dengan jenis surat atau kategori surat, maka hal ini menyebabkan proses pencarian surat menjadi lambat, bahkan tak jarang surat yang dimaksud tidak ditemukan padahal sebenarnya surat itu ada. Hal ini digambarkan pada diagram use case pada Gambar 1. 


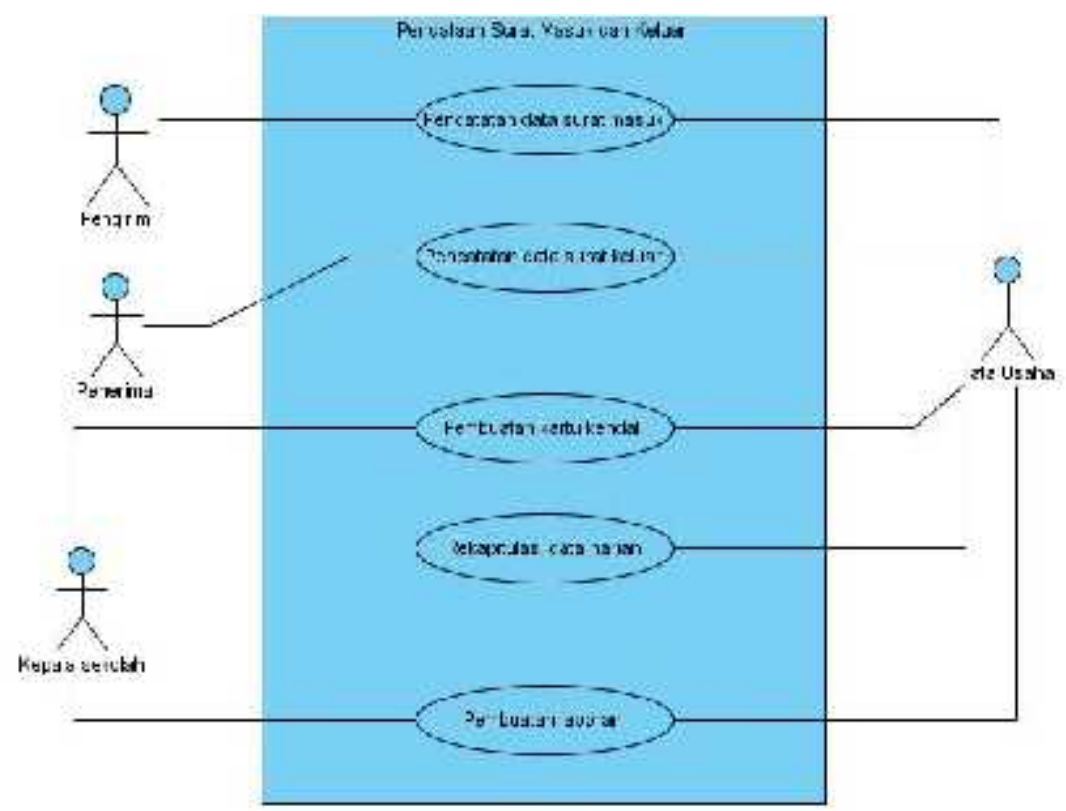

Gambar 1 Usecase Pendataan Surat Masuk Surat Keluar

Gambar 1 tersebut juga menjelaskan saat pemrosesan surat masuk dan surat keluar, dibutuhkan Kartu Kendali yang merupakan berkas untuk verifikasi dari pimpinan yang dalam hal ini adalah Kepala Sekolah, sedangkan pimpinan tidak selalu hadir di tempat untuk melakukan proses verifikasi tersebut, hal ini menyebabkan menumpuknya berkas Kartu Kendali dan proses pendataan menjadi terhambat, penyelesaian tugas menjadi tidak efisien.

\section{RESEARCH METHODE}

Dalam pembuatan Sistem Informasi Surat Masuk dan Surat Keluar, setiap data terkait surat masuk dan surat keluar yang di input akan terekam menjadi sebuah data yang ter-update secara otomatis sehingga informasi dapat diberikan secara cepat, tepat dan akurat sehingga memungkinkan sistem untuk memberikan informasi yang merupakan kebutuhan user yang dalam hal ini adalah bagian Tata Usaha (TU). Sistem membutuhkan data untuk diolah sehingga menghasilkan informasi yang sesuai dengan yang dibutuhkan. Adapun beberapa informasi yang dibutuhkan bagian Tata Usaha adalah informasi hasil verifikasi yang bersumber dari Kartu Kendali, sehingga proses pengolahan surat masuk dan surat keluar dapat dibuatkan laporan hariannya. Selain itu, informasi yang diperlukan adalah hasil dari proses pencarian data surat masuk dan surat keluar yang sudah pernah diproses yang tersimpan dalam database. Dengan kecepatan waktu pencarian informasi dan keakuratan informasi maka tidak terjadi hambatan pendataan surat masuk dan surat keluar, ketidakakuratan laporan ataupun kendala pencarian informasi mengenai surat yang dibutuhkan oleh user.

A. Metode Pengumpulan Data

Terdapat beberapa metode pengmpulan data. Metode pengumpulan data disesuaikan dengan jenis data yang akan dikumpulkan yaitu teknik untuk pengumpulan data primer dan teknik untuk pengumpulan data sekunder.

Pengumpulan data primer pada penelitian ini dilakukan dengan metode survei. Metode survei adalah metode pengumpulan data primer yang menggunakan pertanyaan lisan dan tulisan dari pihak user selaku stakeholder. Metode ini memerlukan adanya kontak atau hubungan antara peneliti dengan subyek (responden) penelitian. Untuk 
memperoleh data yang diperlukan, dilakukan melalui wawancara dengan stakeholder pada SMK Negeri 5 Tangerang.

B. Metode Penelitian

Dari penelitin ini, metode penelitian yang dipakai peneliti dalam melakukan analisa pada SMK Negeri 5 Tangerang adalah sebagai berikut :

- Mempelajari prosedur-prosedur operasional surat masuk maupun surat keluar yang berlaku pada SKM Negeri 5 Tangerang.

- Mempelajari aktivitas dan kegiatan saat surat masuk maupun saat surat keluar di SKM Negeri 5 Tangerang.

- Mempelajari dokumen-dokumen lainnya yang didapat dari SKM Negeri 5 Tangerang.

- Meninjau kekurangan dan kelemahan sistem yang sedang berjalan. Apakah sistem yang berjalan sudah optimal dan mendukung efisiensi kinerja bagian Tata Usaha.

- Membuat rancangan awal (rancangan umum) untuk alur surat masuk dan surat keluar pada SKM Negeri 5 Tangerang, yang selanjutnya akan dipakai sebagai acuan untuk merancang sistem informasi surat masuk dan surat keluar pada SKM Negeri 5 Tangerang.

\section{LITERATURE REVIEW}

Beberapa penelitian sebelumnya ada yang membahas perihal Sistem Surat Masuk Surat Keluar ini, agar pengembangan system informasi Surat Masuk Surat Keluar ini dapat dilakukan dengan optimal, perlu adanya studi pustaka sebagai salah satu penerapan metode penelitian. Perlu adanya identifikasi kesenjangan (identify gaps), menghindari pembuatan ulang, mengidentifikasi metode yang pernah dilakukan ataupun penelitian yang mengembangkan penelitian sebelumnya, mengetahui orang lain yang memiliki spesialisasi serta penelitian sebelumnya sama. Beberapa Literature Review tersebut antara lain :

1. Penelitian yang dilakukan oleh Risma Apriyanijaya,dkk dari ejurnal Mahasiswa Universitas Padjadjaran, Vol.1 No.1 tahun 2012 yang berjudul "Analisa Sistem Informasi Manajemen Administrasi Suratdi Badan Perpustakaan dan Kearsipan Daerah Provinsi Jawa Barat". Penelitian ini menjelaskan perihal kontribusi Informasi bagi pengembangan penelitian dalam bidang kearsipan dan mengungkapkan informasi ilmiah untuk pengembangan ilmu pengetahuan, khususnya ilmu informasi, perpustakaan dan kearsipan yang berkaitan dengan system informasi manajemen administrasi surat dan memberikan hasil, masukan dan gambaran tentang analisis aplikasi system informasi manajemen administrasi surat di Badan Perpustakaan dan Kearsipan Daerah Provinsi Jawa Barat, khususnya untuk membantu pelaksana dalam mengelola administrasi surat masuk dan keluar.

2. Penelitian yang dilakukan oleh Arie Veronica,dkk dari jurnal Speed Journal - Sentra Penelitian Engineering dan Edukasi, Vol.11 No.1 pada tahun 2014 ISSN : 1979-9330, yang berjudul "Rancang Bangun Aplikasi Pengelolaan Surat Masuk dan Surat Keluar Pada Sekolah Menengah Pertama Negeri 2 Nawangan”. Penelitian ini menjelaskan perihal pengelolaan surat Sekolah Menengah Pertama Negeri 2 Nawangan. Sangat diharapkan proses pengelolaan surat baik surat yang masuk maupun surat keluar dapat dilakukan dengan lebih baik, cepat dan mudah. Dengan adanya aplikasi surat masuk dan surat keluar dapat mengurangi penggunaan waktu yang cukup lama dalam pengarsipan surat dan disposisi, mengurangi penggunaan kertas, memperkecil kemungkinan terjadinya kesalahan dalam pencatatan, mempercepat proses pencarian surat, memudahkan pengontrolan disposisi surat serta mudah dalam penggunaan. Pembuatan aplikasi ini juga memudahkan proses komunikasi data antar bagian serta pembuatan laporan yang selalu di 
update dan bisa dilihat berdasarkan laporan bulanan maupun tahunan. Hasil dari penelitian ini adalah Rancang Bangun Aplikasi Pengelolaan Surat Masuk dan Surat Keluar pada Sekolah Menengah Pertama Negeri 2 Nawangan. Dengan adanya sistem ini diharapkan dapat membantu dan mempermudah user dalam mengelola surat, membuat disposisi, memperoleh informasi mengenai surat masuk dan surat keluar.

3. Penelitian yang dilakukan oleh Jati Sasongko, Dwi Agus Diartono dari jurnal Teknologi InformasiDinamik Semarang, Vol.XIV, No.2 pada tahun 2009, ISSN : 0854-9524 yang berjudul "Rancang Bangun Sistem Informasi Manajemen Surat". Penelitian ini menjelaskan perihal administrasi tata usaha. Banyak jumlah surat yang dibuat dan diterima dibagian administrasi tata usaha, sehingga pencarian data akan menjadi tidak efisien dalam hal waktu dan tenaga dengan menggunakan sistem manual. Sehingga pada saat ini diperlukan suatu sistem administrasi manajemen surat yang lebih terstruktur agar dapat mempercepat pencarian data yang ada dan pembuatan laporan. Aplikasi kearsipan ini mempunyai kemampuan sebagai berikutb: aplikasi kearsipan ini dijalankan pada jaringan personal komputer pada bagian ruang tata usaha, petugas tata usaha dapat mengakses aplikasi kearsipan ini dengan memasukkan login user yang benar, dapat melakukan menambah, mengedit, membatalkan, menghapus dan menyimpan surat masuk dan keluar, dapat melakukan pencarian surat masuk dan surat keluar berdasarkan pengirim dan perihal, hasil pencarian dapat dilakukan pengurutan berdasar id surat atau tanggal surat, dapat mencetak laporan berdasarkan hasil pencarian yang telah dilakukan berdasarkan id surat atau tanggal surat.

4. Penelitian yang dilakukan oleh Tiur Gantini, Glenn Griffin dari jurnal Sistem Informasi Bandung, Vol.6, No.2 pada tahun 2011 yang berjudul "Perancangan dan Implementasi Aplikasi Pencatatan Surat dan Disposisi Pada TAUD Polresta Bandung Barat". Penelitian ini menjelaskan perihal palikasi yang terkait dengan pencatatan surat. Aplikasi Pengelolaan Surat dan Disposisi di Unit Taud Polres Bandung Barat ini menangani beberapa hal yaitu Pengelolaan dan pencarian data surat masuk dan surat keluar, Pengelolaan, pencarian data disposisi sampai Pencetakan laporan data surat dan disposisi. Semua pada akhirnya dapat membantu mempercepat pelaporan yang dibutuhkan oleh pimpinan, karena setiap laporan tersimpan secara terkomputerisasi dapat dicetak saat pimpinan butuhkan.

5. Penelitian yang dilakukan oleh Elita, Bakhtaruddin dari jurnal Ilmu Informasi Perpustakaan dan Kearsipan, Vol.2 No.1 pada tahun 2013 yang berjudul "Penanganan Surat Masuk dan Surat Keluar di Sub Bagian Tata Usaha dan Arsip Bagian Umum Sekretariat Daerah Kota Pariaman". Penelitian ini menjelaskan perihal prosedur dalam penanganan surat masuk dan keluar. Penanganan surat masuk meliputi: (1) penerimaan surat; (2) pencatatan surat; (3) penyampaian surat; dan (4) pengolahan surat. Penanganan surat keluar meliputi: (1) pembuatan konsep surat; (2) pengetikan surat; (3) penandatanganan surat; (4) pencatatan surat; (5) penggandaan surat; dan (6) pengiriman. Subbagian Tata Usaha dan Arsip menghadapi beberapa kendala dalam menangani surat, yaitu kurangnya kinerja pegawai, terbatasnya fasilitas yang dimiliki, dan sistem kearsipan yang masih manual. Sehingga perlu penanganan surat lebih baik lagi yaitu dengan menggunakan sistem pola baru kearsipan (kartu kendali). SDM yang dimiliki sebaiknya diperhatikan lagi dan diberikan pelatihan mengenai bagaimana prosedur penanganan surat masuk dan surat keluar yang efektif dan efisien. Selain itu, pengarsipan surat juga dilakukan secara komputerisasi, sehingga pengarsipan informasi yang ada pada surat dapat dilakukan dengan cepat dan tepat. 


\section{PEMBAHASAN}

A. Use Case Diagram Sistem Informasi Pendataan Surat Masuk dan Surat Keluar.

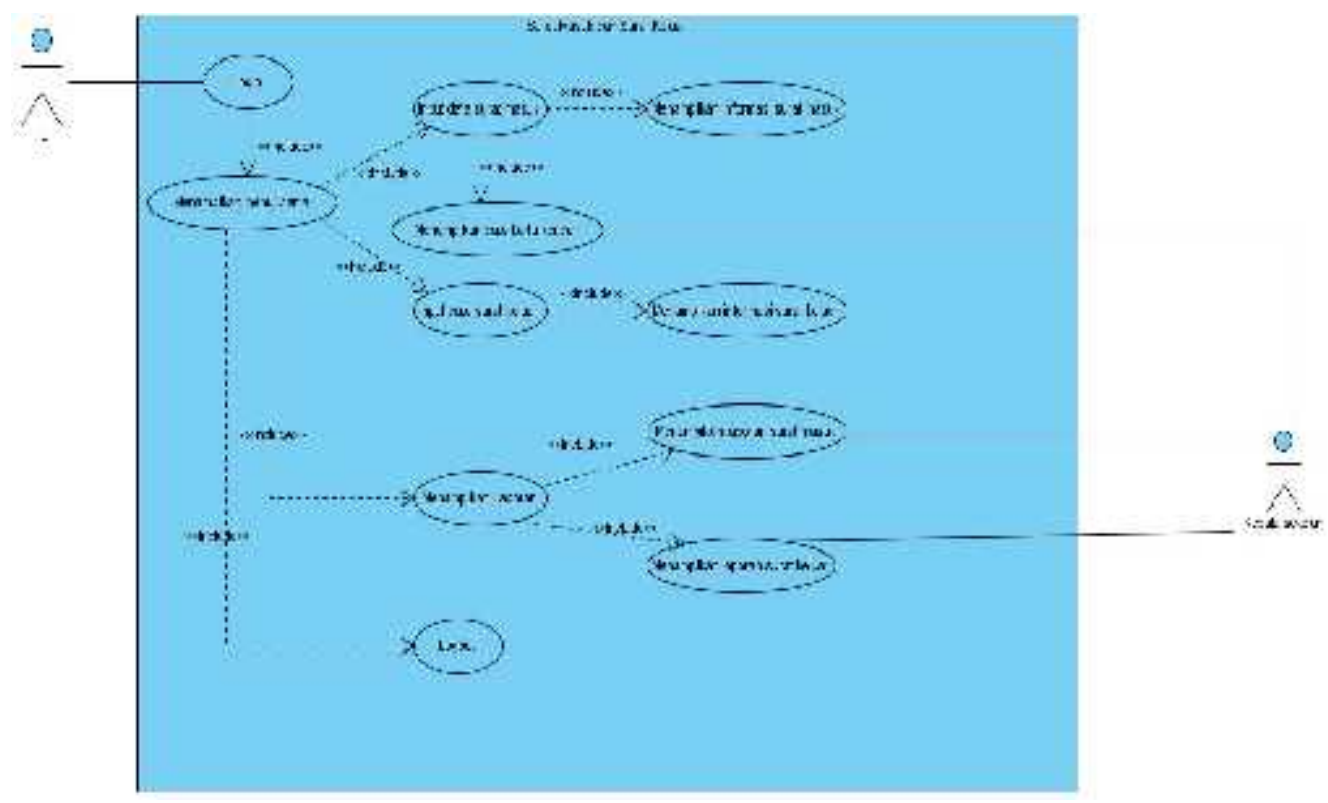

Gambar 2. Sistem Informasi Pendataan Surat Masuk dan Surat Keluar.

Dari hasil penelitian yang dilakukan, sistem dapat direpresentasikan dalam bentuk Use case Diagram pada Gambar 2 diatas. Dimana digambarkan apa saja yang dilakukan oleh user yang dalam hal ini adalah bagian Tata Usaha dan Kepala Sekolah pada Sistem Informasi Pendataan Surat Masuk dan Surat Keluar.

Petugas Tata Usaha akan memasukkan setiap data surat yang masuk ke sekolah, berdasarkan hasil input data surat masuk maka secara otomatis data tersebut akan tampil pada halaman aplikasi Kartu Kendali yang digunakan oleh Kepala Sekolah untuk melakukan proses verifikasi untuk setiap surat yang masuk ke Sekolah, sehingga terdapat kemudahan bagi Kepala Sekolah meskipun tidak sedang berada di Sekolah. Selanjutnya kemudahan bagi petugas Tata Usaha untuk melakukan laporan akhir bulan, karena setiap data yang telah di-input secara otomatis digeneralisasi menjadi laporan akhir bulan surat masuk dan laporan akhir surat keluar oleh system. Sistem juga menyediakan aplikasi untuk kemudahan bagi Kepala Sekolah melakukan monitoring terhadap surat masuk maupun surat keluar secara real time tanpa harus menunggu sampai akhir bulan.

B. Sequence Diagram Sistem Informasi Pendataan Surat Masuk dan Surat Keluar.

Sequence Diagram Sistem Informasi Pendataan Surat Masuk dan Surat Keluar menggambarkan keterkaitan antar objek dan relevansinya terhadap actor-aktor yang terkait dengan system. Lihat gambar pada Gambar 3. 


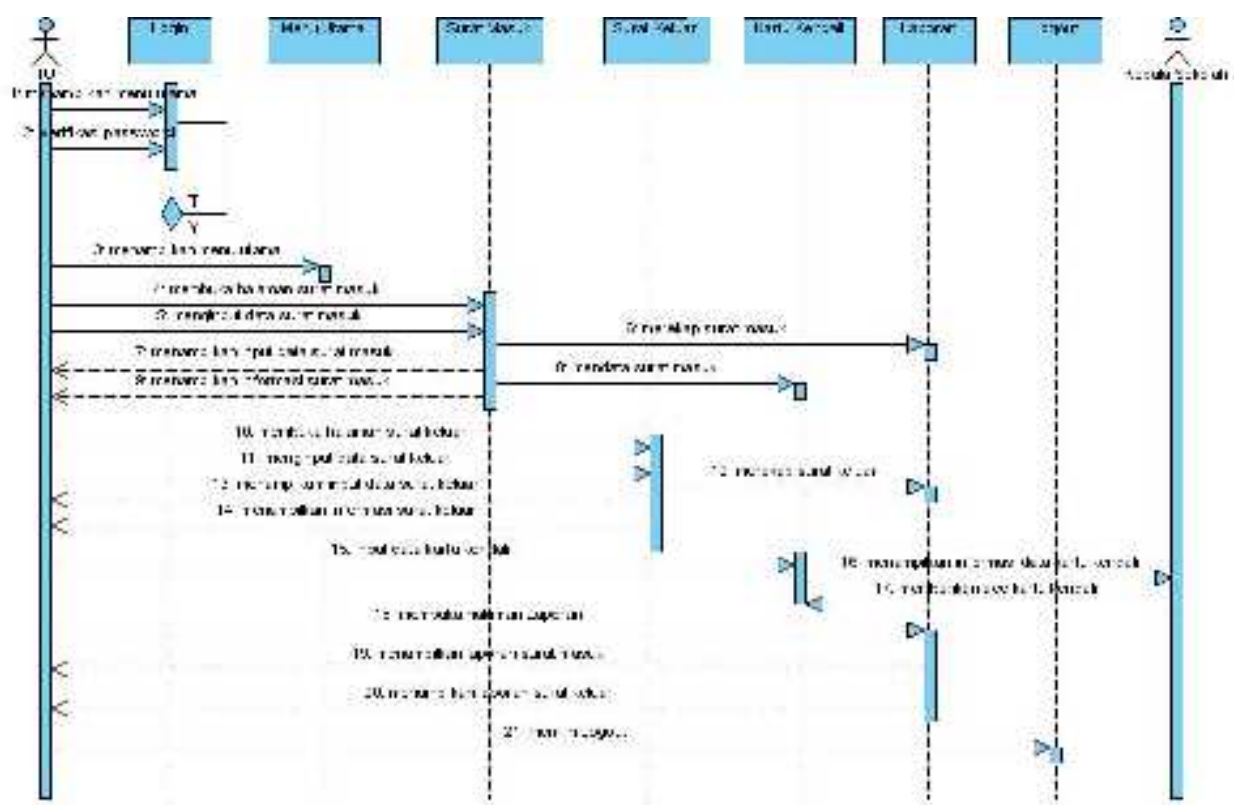

\section{Gambar 3. Sequence Diagram Sistem Informasi Pendataan Surat Masuk dan Surat Keluar.}

C. Class Diagram Sistem Informasi Pendataan Surat Masuk dan Surat Keluar.

Class diagram merupakan diagram yang selalu ada di permodelan sistem berorientasi objek. Class diagram adalah sebuah spesifikasi yang jika diintansiasi akan menghasilkan sebuah objek dan merupakan inti dari pengembangan dan desain berorientasi objek. Class diagram menunjukkan hubungan antar class dalam sistem yang sedang dibangun dan bagaimana mereka saling berkolaborasi untuk mencapai suatu tujuan.

Sebuah Sistem Informasi dikatakan sesuai dengan parameternya jika informasi yang dihasil bisa cepat, akurat dan timelines. Keakuratan informasi yang dihasilkan jika pengolahan database sudah diolah sesuai dengan baik.

Pada class diagram Sistem Informasi Pendataan Surat Masuk dan Surat Keluar ini terdapat 6 tabel, yang terdiri dari 4 tabel utama dan 2 tabel operasional yang berelasi sehingga pengolahannya menghasilkan informasi yang dinamis sesuai kebutuhan user. 


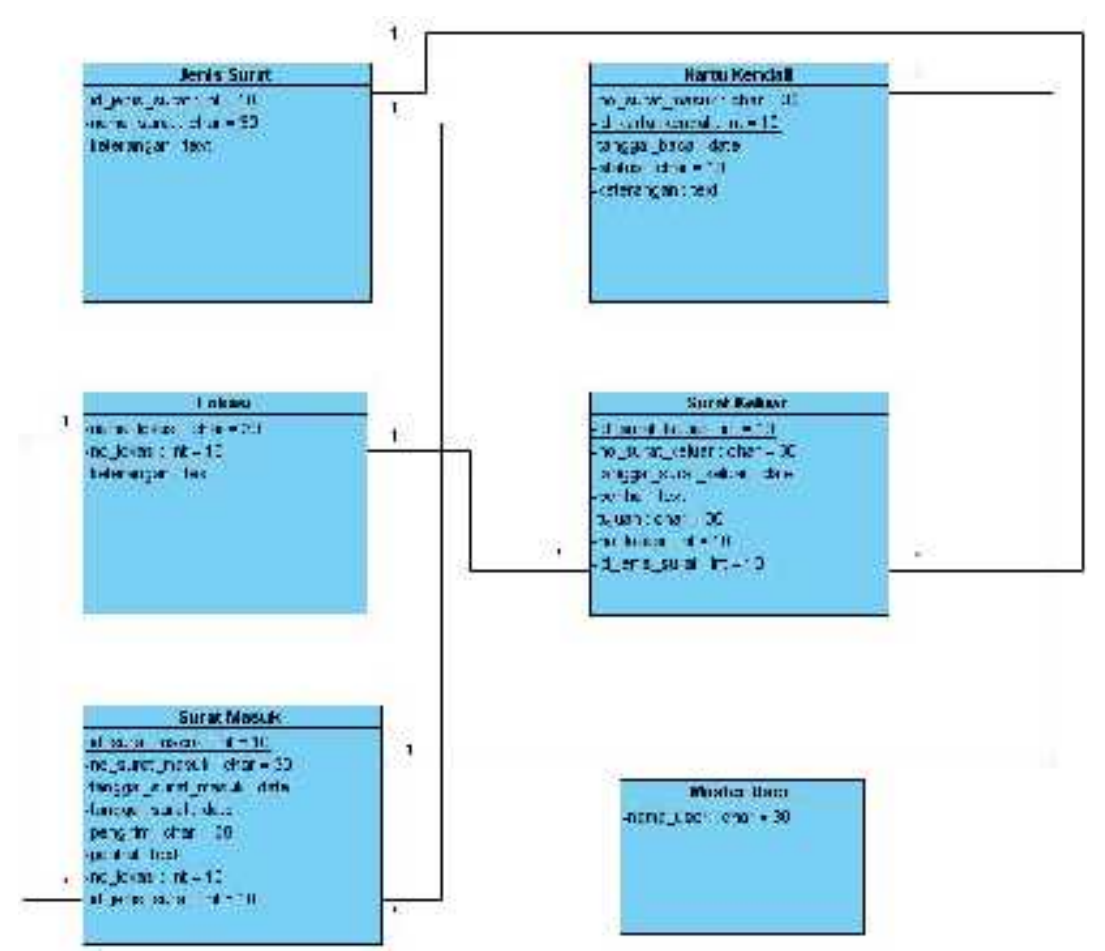

\section{Gambar 4. Class Diagram Sistem Informasi Pendataan Surat Masuk dan Surat Keluar.}

Pada Class Diagram Gambar 4 diatas tampak sebuah table Lokasi, table ini menunjukkan secara system nomor lokasi masing-masing surat berdasarkan jenis suratnya, dengan begitu memberikan efisiensi bagi user (Tata Usaha) dalam melakukan proses pencarian surat.

\section{IMPLEMENTASI}

Setelah membuat rancangan basis datanya yang dirancang dengan class diagram, langkah selanjutnya adalah membuat rancangan tampilan aplikasi. Rancangan tampilan aplikasi dibuat dengan menggunakan Macromedia Dreamweaver dan program aplikasi PHP (Hypertext Preprocessor), dikoneksikan dengan database. Merancang aplikasi dengan program open source (PHP) akan mempermudah pengembangannya karena bisa dijalankan di berbagai platform.

Penggunaan konsep database memberikan kemudahan, yaitu pada proses pencarian data sampai menghasilkan informasi yang efisien berupa laporan yang cepat dan akurat sesuai kebutuhan bagian Tata Usaha.

Berikut tampilan dari Sistem Informasi Surat Masuk dan Surat Keluar pada SMK Negeri 5 Tangerang. 


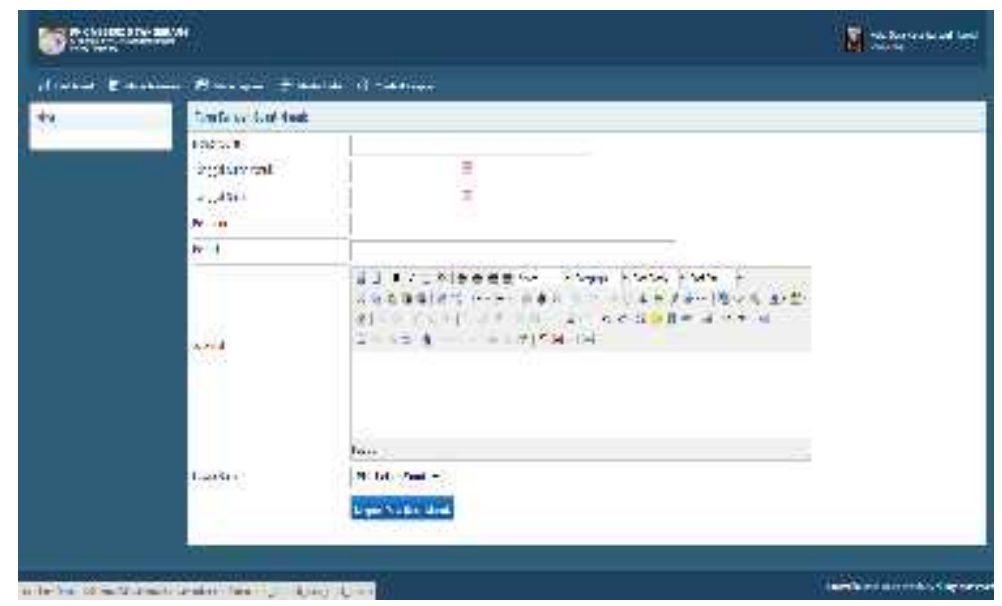

Gambar 5. Halaman Input Surat Masuk

Halaman aplikasi ini diperuntukkan bagi petugas Tata Usaha saat memasukkan data surat yang masuk ke sekolah. Setiap komponen yang ada pada halaman ini disesuaikan dengan prosedur yang berlaku pada SMK 5 Tangerang. Efisiensi yang diberikan oleh system adalah berdasarkan hasil input data surat masuk maka secara otomatis data tersebut akan tampil pada halaman aplikasi Kartu Kendali yang digunakan oleh Kepala Sekolah untuk melakukan proses verifikasi untuk setiap surat yang masuk ke Sekolah, aplikasi tersebut terlihat pada Gambar 6.

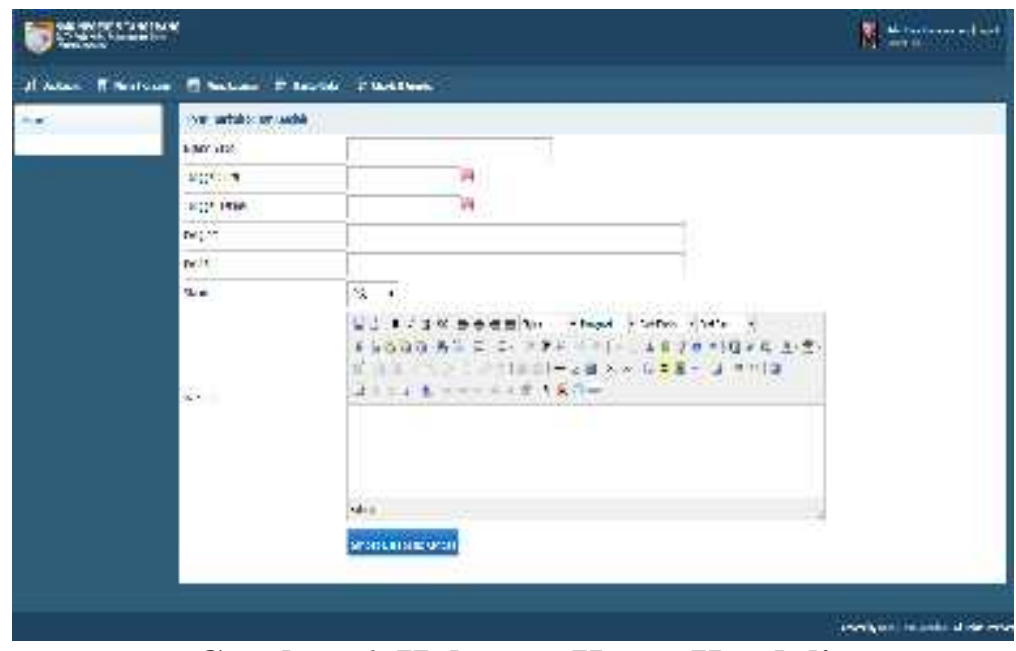

Gambar 6. Halaman Kartu Kendali

Banyaknya surat yang masuk tidak akan menjadi kendala lagi bagi Kepala Sekolah untuk melakukan proses verifikasi meskipun sedang tidak berada di Sekolah, efisiensi ini-pun berdampak pada petugas Tata Usaha untuk melakukan proses pelaporan harian maupun laporan akhir bulan. Setiap data surat yang di-input akan digeneralisasi oleh system menjadi laporan, baik laporan harian maupun laporan setiap akhir bulan tanpa user harus lakukan rekap manual. Tampilan aplikasi untuk laporan seperti pada Gambar 7 dibawah ini berdasarkan tanggal yang dibutuhkan. 


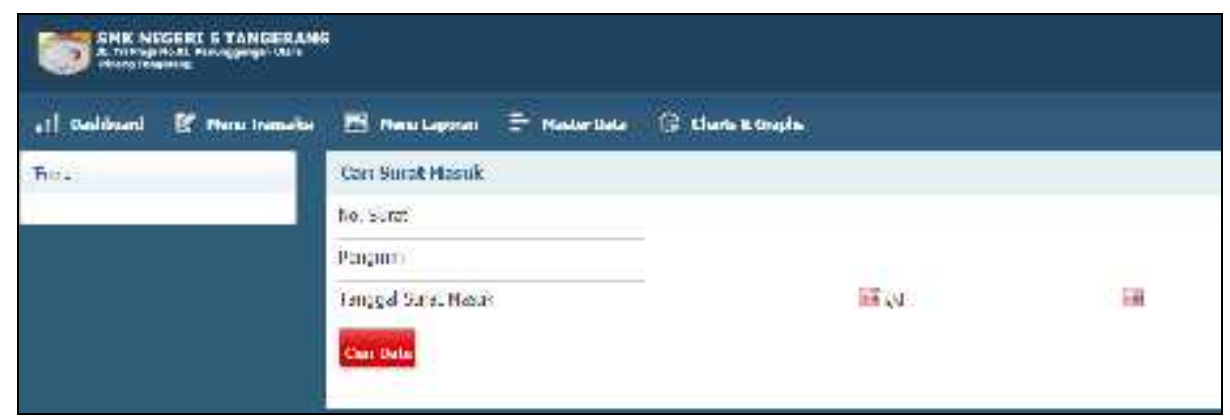

\section{Gambar 7. Menu laporan Surat Masuk}

Gambar 8 dibawah ini digunakan untuk proses input data setiap surat yang keluar.

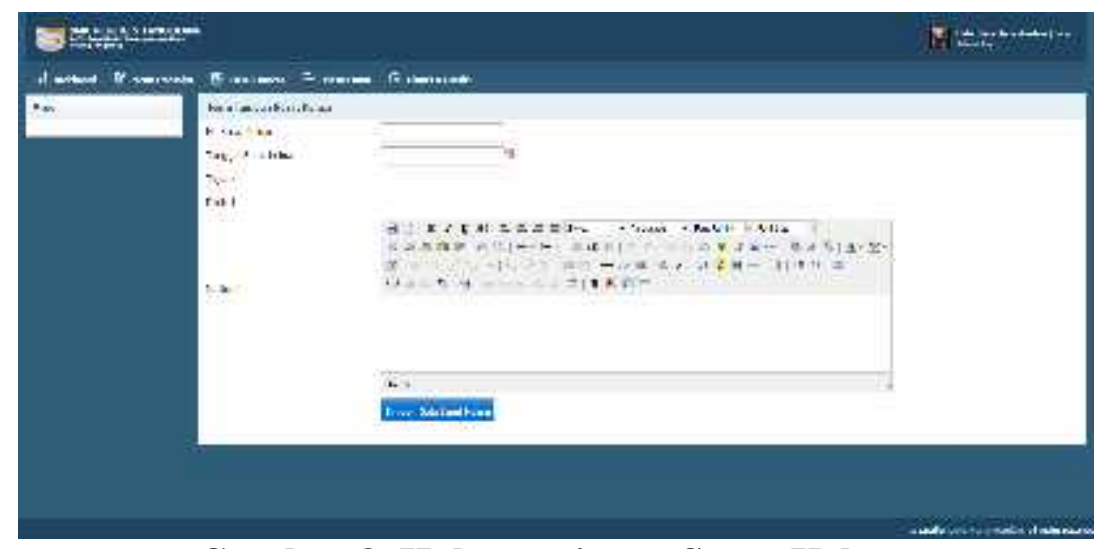

Gambar 8. Halaman input Surat Keluar

Sama halnya dengan surat masuk, setiap surat keluar yang di-input akan digeneralisasi oleh system menjadi laporan, baik laporan harian maupun laporan setiap akhir bulan tanpa user harus lakukan rekap manual. Aplikasinya ditampilkan pada gambar 9 dibawah ini berdasarkan tanggal yang dibutuhkan.

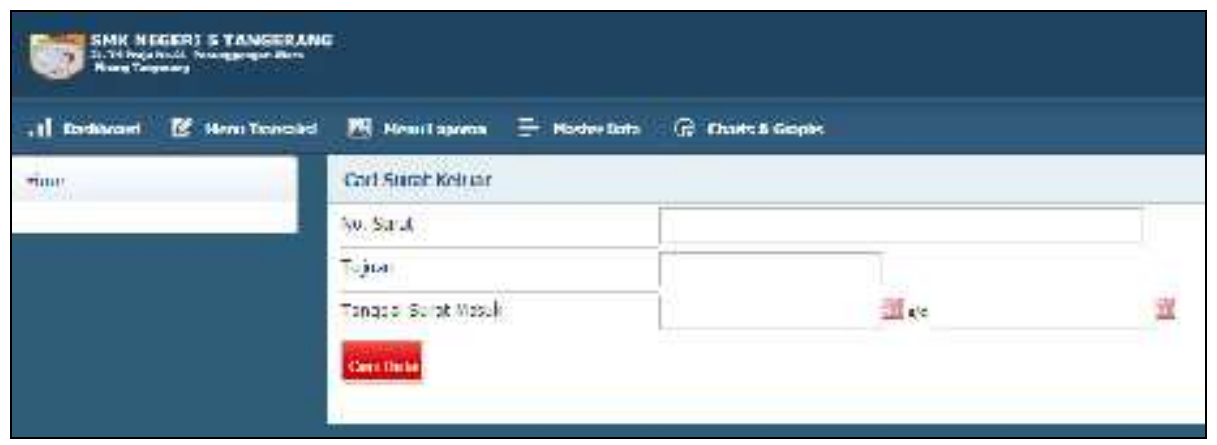

Gambar 9. Menu Laporan Surat Keluar

Selanjutnya adalah tampilan menu pencarian surat. Tampilan aplikasi pada Gambar 10 memberikan efisiensi bagi user (Tata Usaha) dalam melakukan pencarian surat yang sewaktu-waktu dibutuhkan. Informasi mengenai surat yang dibutuhkan akan langsung ditampilkan dengan meng-input data pada aplikasi yaitu No.Surat atau Jenis Surat yang dicari. 


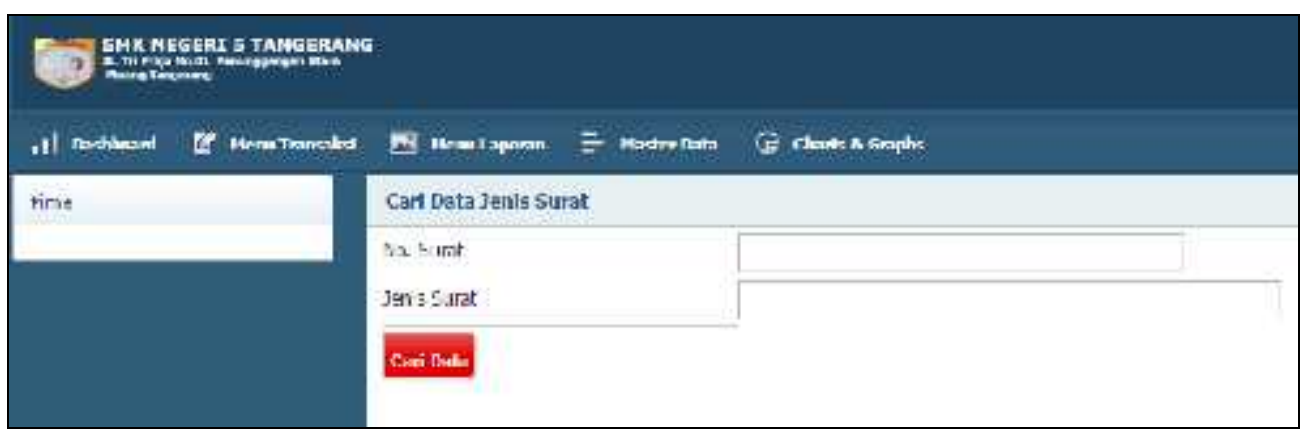

Gambar 10. Menu Pencarian Surat Masuk atau Surat Keluar

\section{KESIMPULAN}

Dengan adanya aplikasi yang disediakan untuk Kepala Sekolah, maka tidak ada hambatan lagi bagi Tata Usaha dalam memproses laporan harian surat masuk dan surat keluar, karena Kepala Sekolah bisa melakukan proses verifikasi Kartu Kendali dimanapun berada, tidak harus saat berada di Sekolah. Dengan kecepatan waktu pencarian informasi, user (Tata Usaha) tidak lagi membutuhkan waktu yang lama saat mencari informasi mengenai surat-surat yang dibutuhkan, baik itu surat masuk maupun surat keluar. Sistem juga memberikan kemudahan bagi user (Tata Usaha) saat akan membuat laporan setiap akhir bulan, karena data surat masuk dan surat keluar yang dimasukkan setiap hari secara otomatis digeneralisasi menjadi laporan, sehingga user tidak perlu lagi merekap ulang data surat masuk dan surat keluar.

\section{DAFTAR PUSTAKA}

[1] Arie Veronica,dkk. Rancang Bangun Aplikasi Pengelolaan Surat Masuk dan Surat Keluar Pada Sekolah Menengah Pertama Negeri 2 Nawangan. jurnal Speed Journal, Vol.11 No.1 pada tahun 2014 ISSN : 1979-9330.

[2] Risma Apriyanijaya,dkk. Analisa Sistem Informasi Manajemen Administrasi Suratdi Badan Perpustakaan dan Kearsipan Daerah Provinsi Jawa Barat. ejurnal Mahasiswa Universitas Padjadjaran, Vol.1 No.1 tahun 2012. Diakses pada tanggal 17/3/2015 dari : http://journal.unpad.ac.id/ejournal/article/view/1719/0

[3] Jati Sasongko, Dwi Agus Diartono. Rancang Bangun Sistem Informasi Manajemen Surat. jurnal Teknologi InformasiDinamik Semarang, Vol.XIV, No.2 pada tahun 2009, ISSN : 0854-9524. Diakses pada tanggal 17/3/2015 dari : http://download.portalgaruda.org/article.php?article=7447\&val=544

[4] Tiur Gantini, Glenn Griffin. Perancangan dan Implementasi Aplikasi Pencatatan Surat dan Disposisi Pada TAUD Polresta Bandung Barat. jurnal Sistem Informasi Bandung, Vol.6, No.2, 2011. Diakses pada tanggal 17/3/2015 dari : http://repository.maranatha.edu/571/1/Perancangan\%20dan\%20Implementasi\%20Aplik asi\%20Pencatatan\%20Surat.pdf

[5] Elita, Bakhtaruddin. Penanganan Surat Masuk dan Surat Keluar di Sub Bagian Tata Usaha dan Arsip Bagian Umum Sekretariat Daerah Kota Pariaman. jurnal Ilmu Informasi Perpustakaan dan Kearsipan, Vol.2 No.1, 2013. Diakses pada tanggal 17/3/2015 dari : http://ejournal.unp.ac.id/index.php/iipk/article/viewFile/2299/1920

[6] Edhy Sutanta. 2011. "Basis Data dalam Tinjauan Konseptual", Penerbit Andi : Yogyakarta.

[7] Budi Raharjo. 2010. "Modul Pemrograman Web", Penerbit Modula : Bandung.

[8] Prabowo Pudjo Widodo. 2011. "Menggunakan UML”, Penerbit Informatika : Bandung. 